\title{
MORPHOLOGICAL AND SOME BIOLOGICAL ASPECTS OF THE PEACH FRUIT FLY, BACTROCERA ZONATA (SAUND.) (DIPTERA: TEPHRITIDAE)
}

\author{
HOSNI, MARWA E. ${ }^{1}$, M. M. EL-HUSSEINI ${ }^{2}$, A. H. EL-HENEIDY ${ }^{1}$ \\ and FATMA A. ATALLAH ${ }^{1}$
}

1. Dept. of Biological Control, Plant Protection Research Institute, ARC, Giza, Egypt.

2. Dept. of Economic Entomology and Pesticides, Faculty of Agriculture, Cairo University, Giza, Egypt.

(Manuscript received 27 May 2012)

\begin{abstract}
The peach fruit fly (PFF), Bactrocera zonata (Saunders) (Diptera: Tephritidae) is one of the serious tephritid insect pests attacking tropical and subtropical fruits. In Egypt, the pest is widespread over most of the Egyptian governorates causing serious problems to many fruit crops. The present study aimed to focus on some morphological and biological characteristics of different stages of the PFF under laboratory conditions. Different stages of the PFF were described, measured and illustrated. Biological studies included, durations of different immature stages, fecundity, adult longevity, survival rate and sex ratio. All studies were carried out under the laboratory conditions of $25 \pm 2{ }^{\circ} \mathrm{C}, 54-65 \%$ R.H. and 14:10 L:D photoperiod. Total developmental period of PFF (from egg deposition to adult emergence) averaged 18.7 days. The female required 13-21days post emergence to start laying eggs. Total number of eggs/female averaged 235.72. Percentage of adult emergence was $58 \%$ and sex ratio (females: males) was 1.2: 1.0. Female and male longevity attained 50.6 and 47.3 days for the fed individuals and 2.8 and 3.1 days for unfed ones, respectively.
\end{abstract}

\section{INTRODUCTION}

The dipteran family Tephritidae includes of over 4000 species, of which nearly 700 species belong to Dacine fruit flies (Fletcher, 1987). Nearly 250 species are of economic importance, and distributed widely in temperate, sub-tropical and tropical regions of the world (Christenson and Foote, 1960).

The peach fruit fly (PFF), Bactrocera zonata (Saunders) (Diptera: Tephritidae) is one of the serious insect pests attacking tropical and subtropical fruits (Fletcher, 1987) not only in Egypt but also in many other countries. This pest is originally an Indian species, firstly reported from Bengal. It is now widespread over India, Pakistan, Nepal, Bangladesh, Srilanka, Burma and evidently over southeast Asia. In Egypt, the pest is present and widespread over most of the Egyptian governorates causing serious problems to many fruit crops. B. zonata has caused an estimation of 190 million EURO damage a year in Egypt (OEPP/EPPO, 2005). 
B. zonata has been recorded on over 50 cultivated and wild plant species, mainly those with fleshy fruits. Its main host plants are guava, mango and peach, while the secondary hosts include apricot, fig and citrus. It has been frequently recovered from peach, hence, it is called the peach fruit fly and also due to its serious damage to guava, it is called "guava fruit fly" (Hussain, 1995).

In the last decade, many ecological and biological aspects of the pest were studied to reach proper methods for its control. In Egypt, most researchers initially reared PFF on natural hosts specially, guava fruits to study its biology (Mohamed, 2000). Afterwards, artificial diet was used to obtain large production form eggs and larvae. In 2003, El-Gendy reared larvae of $B$. zonata on wheat bran artificial diet and different host plants and compared the durations of different stages and larval mortality. He reported that the shortest larval duration was recorded on guava while the longest occurred on sour orange in comparison to artificial diet. Amin (2003) evaluated two larval diets, the first one which was reported by Qureshi et. al., (1974), while the other was mentioned by Awadallah (1978) depending upon durations and survival percentages of immature stages. The second diet was most preferable for rearing larvae as it indicated lowest larval duration and highest percentage of larval survival. In addition, it was economic and practical for laboratory manipulation.

El-Naggar (2004) recorded longest incubation period and high hatchability percentages on apple, the shortest was on peach. The longest pupal duration and mortality percentages of $B$. zonata were on apple, peach, guava and apricot, respectively. The PFF was reared at different constant temperatures $\left(15-40^{\circ} \mathrm{C}\right.$ and $60-70 \%$ R.H) by Afia (2007), when incubation periods, larval duration, lower threshold of larval development and average thermal units required under different temperatures were studied. Farag (2009) studied some biological aspects of PFF different stages under three constant temperatures $\left(20,25\right.$ and $\left.30 \pm 1^{\circ} \mathrm{C}\right)$ to estimate heat-unit requirements necessary for the development of different stages to complete one generation.

Study of insect development and morphological description is a useful tool for evaluation of control programs. Morphology, number of instars, durations of stages is basic aspects of the biology under known conditions that may provide material for comparative studies when the parameters are changed. These results may also be used to develop ecological control models under laboratory or field conditions.

The present study was carried out to shed light on some morphological and biological characteristics of different stages of $B$. zonata under laboratory conditions. 


\section{MATERIALS AND METHODS}

\section{Rearing of $B$, zonata}

Flies of $B$. zonata were obtained from a laboratory stock culture at the Biological Control Department, Plant Protection Research Institute, Agricultural Research Center at Giza. Rearing technique was more or less similar to that of the Mediterranean fruit fly, Ceratitis capitata (Wied.) but with some variations in the ingredients of the artificial larval diet. The rearing was carried out under the laboratory conditions of $25 \pm 2{ }^{\circ} \mathrm{C}$, $54-65 \%$ R.H. and 14: $10 \mathrm{~L}$ : D photoperiod. Eggs of the PFF were collected daily from special egg-laying collector and placed on an artificial diet in plastic trays covered with cloth lids, placed in an incubator at $25 \pm 1^{\circ} \mathrm{C}$ and left for hatching and larval development. Third larval instars were transferred to trays furnished with a thin layer of sand for pupation. Pupae were sieved from the sand and transferred to adult cages till emergence. Adult flies were reared in cages (35 $\times 30 \times 30 \mathrm{~cm})$.

Flies were encouraged to lay eggs by providing them with egg collectors of plastic mandarins, perforated from the upper part and contained water inside to keep moisture for eggs. Eggs were collected daily and reared on larval artificial diet, which was the same for the Medfly, artificial diet (described by Boller, 1985), but with some modifications as follows: (1000 g short wheat, $250 \mathrm{~g}$ molasses or (300 g sugar), $250 \mathrm{~g}$ yeast, $10 \mathrm{~g}$ sodium benzoate, $1 \mathrm{ml}$ Conc. $\mathrm{HCL}$ (or $20 \mathrm{ml} \mathrm{HCL} 2 \mathrm{~N}$ ) and $300 \mathrm{ml}$ water).

Adult flies were fed mainly on sources of sugar, protein and water. Cotton wool soaked with nutritional material served as food source. For protein requirement, mixture of sugar and protein hydrolyzed enzymatic (at a ratio of 3:1, respectively), besides an artificial diet was provided. This diet was described by Masood et al. (2006), as follows: (2 pieces Bananas, 6 pieces Egg yolk, 4 table- spoon Honey, 2 table-spoon Vit. B. Complex, 1 table-spoon Yeast, and 8 table-spoon Sugar). The ingredients were mixed in a blender to make a thick syrup solution. For further use, the diet was kept in the refrigerator.

\section{Morphological and Biological studies}

\subsection{Morphology of $B$. zonata immature stages}

A set of 50 individuals from each stage was collected from the laboratory stock culture. Each stage was measured and described using a stereomicroscope. For other characteristics of the body such as: anterior, posterior spiracles and mandibles, the larvae were dissected in a saline solution, mounted in Hoyer's medium and described using a microscope $(10 \times 40)$. 


\subsection{Biology of B. zonata}

\subsubsection{Durations of immature stages}

Thirty newly deposited eggs were collected from the rearing colony and used as starter for the biological studies. Each individual egg was placed on artificial medium in a small Petri dish and covered with transparent organdy cloth. Petri dishes were incubated at $25 \pm 1^{\circ} \mathrm{C}$. and eggs were observed daily until hatching. Larvae were left to complete their development inside the medium until occurred on the surface and jumped out from the Petri dishes to pupate in the sand.

\subsubsection{Fecundity}

Twenty mated females of PFF were used as replicates until their death. Plastic mandarins (had holes in their sides and provided with water) were placed in small cages containing small pieces of the mixture of sugar and protein hydrolyzate and a source of water served as oviposition site. Daily number of eggs laid by each female was counted. Pre-ovipositional, ovipositional and post-ovipositional periods were estimated.

\subsubsection{Survival and Sex ratio}

Hundred newly formed pupae were collected and placed into a plastic jar covered with organdy until adult emergence. Survival rate was estimated. Numbers of emerged adults were counted.

\subsubsection{Longevity}

Newly formed pupae were placed individually into small glass vials until adult emergence. Two groups (30 pairs, males and females each) were left to complete their life span, the $1^{\text {st }}$ group was left unfed while the $2^{\text {nd }}$ was fed by a mixture of sugar and protein hydrolyzate and a source of water. Longevity of each sex was estimated.

All biological studies were carried out under the above mentioned laboratory conditions of $25 \pm 2{ }^{\circ} \mathrm{C}, 54-65 \%$ R.H. and 14: 10 L: D photoperiod.

3. Statistical analysis was carried out using the F-Test.

\section{RESULTS AND DISCUSSION}

\section{Morphological Studies of $B$, zonata immature stages}

Measurements of different PFF stages are summarized in table (1) and figures (1-12) illustrated characteristics of different stages.

\subsection{Egg stage}

Eggs of $B$. zonata are deposited by female ovipositor under the skin of the fruits usually in groups. Eggs are white and appear elliptic in shape tapered at both 
ends and have a micropyle at one end (Fig. 1). The egg averaged 1220.6 $\pm 8.06 \mu$ $(1200-1250 \mu)$ long and $260 \pm 6.58 \mu(250-300 \mu)$ wide.

\subsection{Larval stage}

Larva of the tephritid flies usually passes through three larval instars, described as follows:

\subsubsection{First instar larva (L1)}

The first instar larva is creamy-white in color, seems typically a mandibulate type larva, with an orange triangular head to support the mandibular muscles (Fig. 2). It measured $1230 \pm 8.06 \mu(1200-1250 \mu)$ long and $310 \pm 6.58 \mu(300-350 \mu)$ wide. Mandibles, moderately sclerotized, with relatively small mouth hooks and each with a large preapical hooked tooth (Fig. 5). They measured $100 \mu$ long and $50 \mu$ wide. In this stage, anterior spiracles are hardly visible under light microscopy (Fig. 6). This note was recorded in Dacus tryoni when Elson-Harris (1988) studied the morphology of immature stages of $D$. tryoni and found that the anterior spiracles of $1^{\text {st }}$ instar was reduced to minute simple open pits, hardly visible under light microscopy but visible under scanning electronic microscopy (SEM). Posterior spiracles, each with 2 slits, are obvious but with lightly sclerotized spiracular plates (Fig. 7).

\subsubsection{Second instar larva (L2)}

The second instar larva is larger than (L1) (Fig. 3) measured $4140 \pm 14.35 \mu(4100-$ $4200 \mu)$ and $665 \pm 7.54 \mu(650-700 \mu)$ in length and width, respectively. It has heavily sclerotized, cephalopharyangeal skeleton, well-developed mouth hooks, characterized with medium light color preapical tooth half the size of apical tooth (Fig.5). The mandibles measured $150 \mu$ long and $100 \mu$ wide. Anterior and posterior spiracles are clearly observed in this stage (Fig. 7).

\subsubsection{Third instar larva (L3)}

The third instar larva is creamy-white and appears as a legless maggot (Fig. $5)$. It feeds on fruit pulp measuring $8258 \pm 7.5 \mu(8250-8300 \mu)$ long and $1400 \pm 40.34 \mu$ $(1250-1500 \mu)$ wide. Mandibles are strong, dark and easy to recognize. Each mandible measures $200 \mu$ in length and $150 \mu$ in width, heavily sclerotised, partially protruding mouth hooks large and symmetrical with curved tips but without preapical teeth on concaved surface (Fig. 5). Anterior and posterior spiracles are similar to those of the $2^{\text {nd }}$ instar but heavily sclerotized (Figs. 6 and 7).

Mature larvae dropped later to the ground through conspicuous holes in the fruit, for pupation in the soil. When disturbed, the larvae double over and jump. The present results agree with those reported by FAO/IAEA (2000) that larvae may grow to a length of about 7-10 $\mathrm{mm}$ within the fruit. 


\subsection{Pupal stage}

The third larval instar of the tephritid flies usually pupates in its last molting skin in soil. At the beginning of this stage, the puparium becomes yellowwhite. The puparium turns darker and harder by the time (Fig. 8). The full-developed pupa measured $4770 \pm 8.06 \mu(4750-4800 \mu)$ long and $2010 \pm 6.58 \mu(2000-2050 \mu)$ wide. Puparium is barrel-shaped, reddish brown (Fig. 9), bearing the third instar larva's anterior and posterior spiracles obvious but non-functioning (Figs. 10 and 11).

\subsection{Adult stage}

B. zonata adult is about the size of the housefly. It is reddish brown with yellowish abdominal cross bands. Wings are transparent with a small brown spot on its tip (Fig. 13). Antennae are short and less than the vertical length of the head. Males and females are easy to recognize through the posterior end of the abdomen (Fig. 14).

Table 1. Measurements of the different stages of Bactrocera zonata, all measurements were done by using a micrometer lens $(1 \mathrm{~mm}$, scale $=50 \mu)$

\begin{tabular}{|l|c|c|c|c|}
\hline \multirow{2}{*}{ Stage } & \multicolumn{2}{c|}{ Mean } & \multicolumn{2}{c|}{ Range } \\
\cline { 2 - 5 } & Length & Width & Length & Width \\
\hline Egg & $1220.6 \pm 8.06$ & $260 \pm 6.58$ & $1200-1250$ & $250-300$ \\
\hline Larva $1^{\text {st }}$ instar & $1230 \pm 8.06$ & $310 \pm 6.58$ & $1200-1250$ & $300-350$ \\
\hline $2^{\text {nd }}$ instar & $4140 \pm 14.35$ & $665 \pm 7.54$ & $4100-4200$ & $650-700$ \\
\hline $3^{\text {rd }}$ instar & $8258 \pm 7.5$ & $1400 \pm 40.34$ & $8250-8300$ & $1250-1500$ \\
\hline Pupa & $4770 \pm 8.06$ & $2010 \pm 6.58$ & $4750-4800$ & $2000-2050$ \\
\hline
\end{tabular}

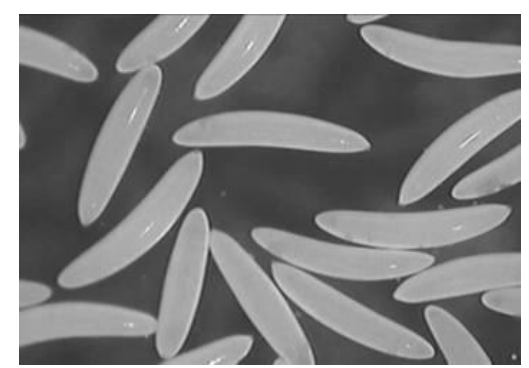

Fig. 1. Eggs of B. zonata

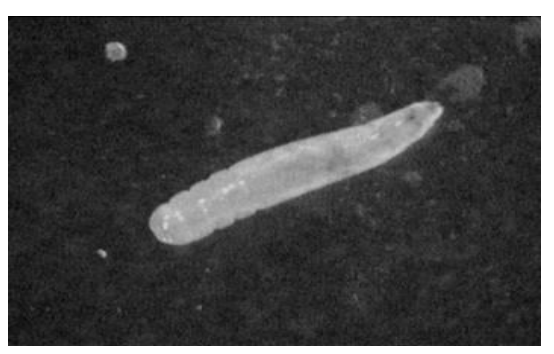

Fig. 2. First instar larva of $B$. zonata 


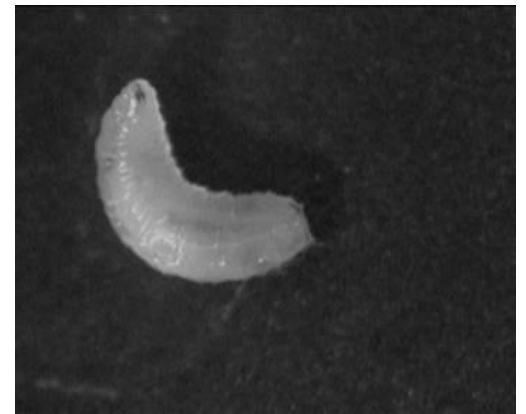

Fig. 3. Second instar larva

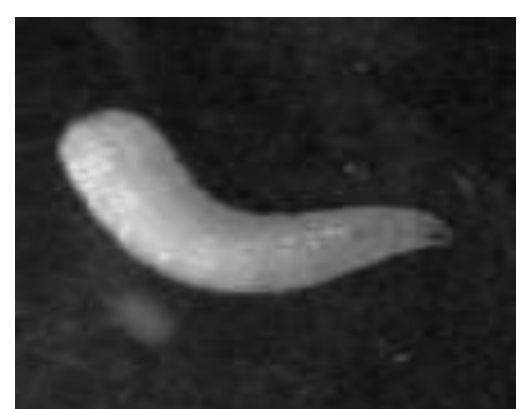

Fig. 4. Third instar larva

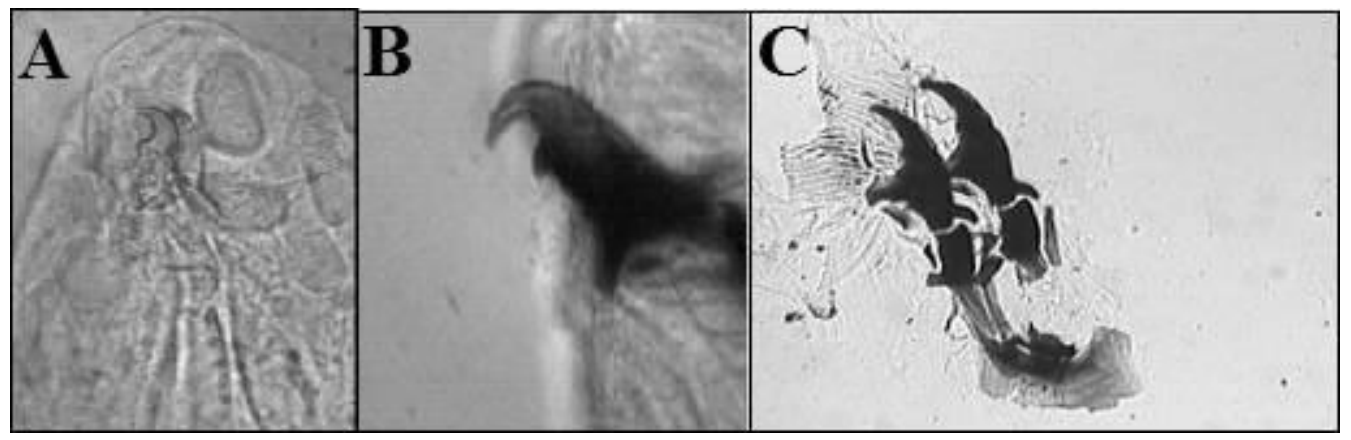

Fig. 5. Mandibles of A) $1^{\text {st }}$ instar, B) $2^{\text {nd }}$ instar and C) $3^{\text {rd }}$ instar larvae of $B$. zonata

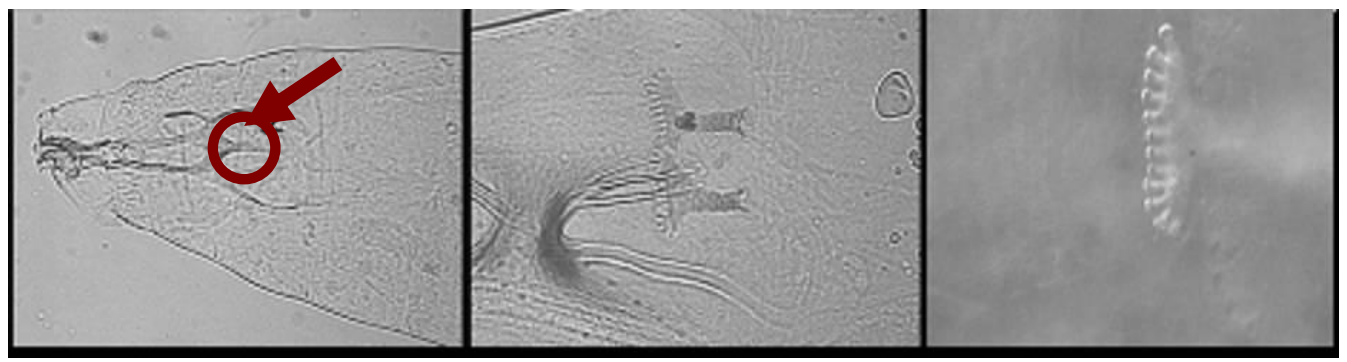

Fig. 6. Anterior spiracle of $1^{\text {st }}, 2^{\text {nd }}$ and $3^{\text {rd }}$ instar larvae of $B$. zonata

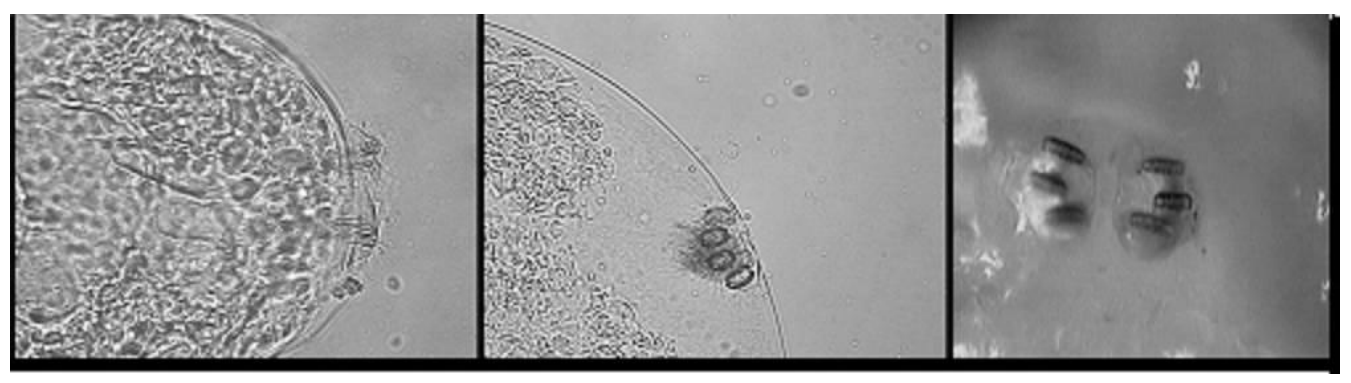

Fig. 7. Posterior spiracle of $1^{\text {st }}, 2^{\text {nd }}$ and $3^{\text {rd }}$ instar larvae of $B$. zonata 


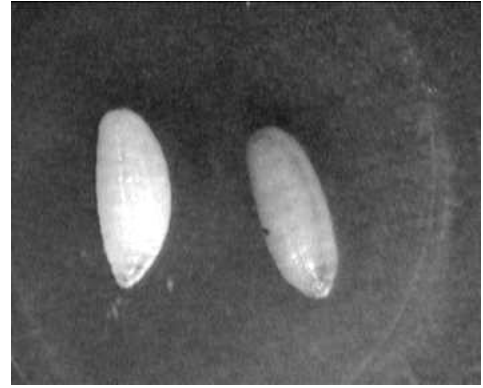

Fig. 8. A) Newly yellow-white formed pupa of B. zonata

B) Old yellow-brown pupa.

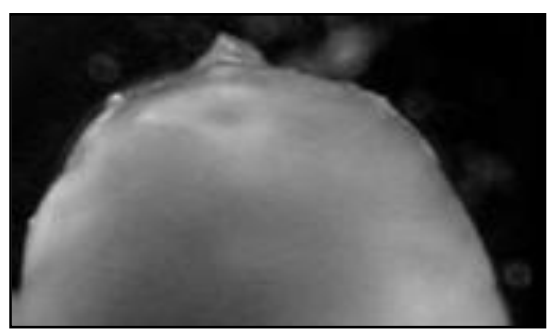

Fig. 10. Anterior end of B. zonata pupa

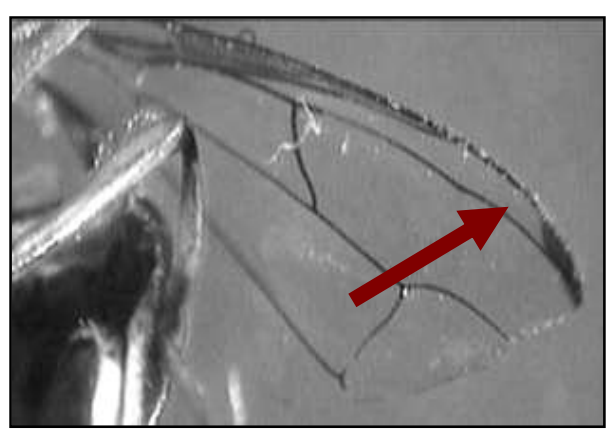

Fig. 12. Spot on the wing tip of $B$. zonata

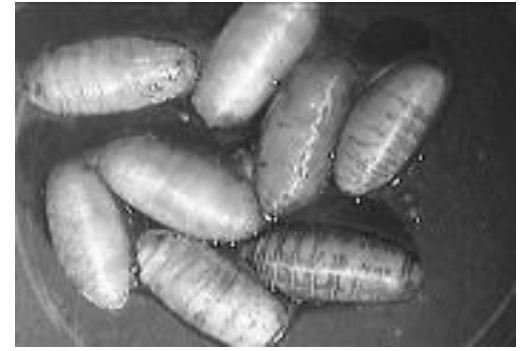

Fig. 9. Pupa of B. zonata

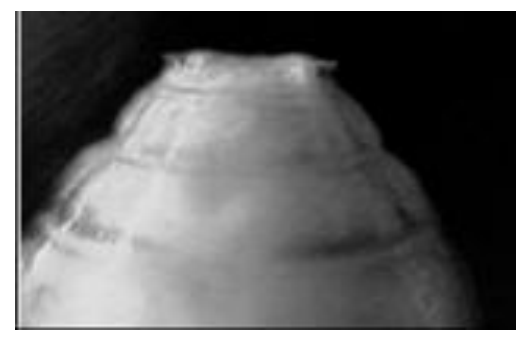

Fig. 11. Posterior end of $B$. zonata pupa (takes the form of posterior spiracle)

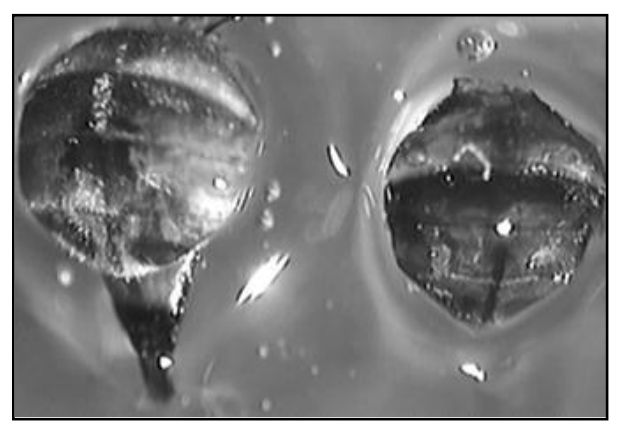

Fig. 13. Female and male posterior end of the abdomen of $\boldsymbol{B}$, zonata

\section{Biological Studies of B. zonata}

\subsection{Durations of immature stages}

The durations of various immature stages of $B$. zonata are presented in table (2). 


\subsubsection{Incubation period of egg stage}

The egg incubation period ranged between 1 and 3 days, with an average of 2.7 days. The present results agree with those of FAO/ IAEA (2000), which reported that under favorable conditions, the eggs hatched to larvae within 2 days. This incubation period may be delayed when temperatures is below normal. Hussain (1995) recorded that the $B$. zonata egg incubation ranged 24-43 hrs. Nearly similar results had been reported by many authors such as, Mohamed (2002), Duyck et al. (2004), Afia (2007) and Farag (2009). They reported 3.0, 2.0, 2.3 and 2.2 days at $25^{\circ} \mathrm{C}$, respectively.

\subsubsection{Developmental period of larval stage}

The three larval instars occupied 5-7 days, with an average of 5.8 days. This result is in accordance with the findings of Qureshi et. al., (1993), Mohamed (2002), Afia (2007) and Farag (2009) who reported 5.8-12.2, 6.1-13.1, 5.4-14.8 and 5.3-12.8 days at $20-30{ }^{\circ} \mathrm{C}$, respectively as ranges of total developmental larval period.

\subsubsection{Duration of pupal stage}

As shown in table (2), the duration of pupal stage averaged 10.2 days, ranged between 9 and 11 days. This result was similar to that reported by Qureshi et. al., (1993), El-Gendy (2003), Afia (2007) and Farag (2009) who recorded 10.3, 10.8, 11.2 and 10.8 days at $25^{\circ} \mathrm{C}$, respectively. Mohamed (2000) reported shorter pupal duration (7.7 days) at the same temperature on the natural host guava fruits.

\subsubsection{Total developmental period}

Newly emerged adults are not sexually matured, thus the flies attained their sexual maturity within a mean of 16.6 days. The total developmental period of $B$. zonata (from egg deposition to adult emergence) averaged 18.7 days (Table 2).

\subsection{Ovipositional periods and fecundity}

Table (2) shows that the female required 13-21 days after emergence to start laying eggs. Pre-ovipositional period averaged $16.6 \pm 1.97$ days at $25^{\circ} \mathrm{C}$. The daily mean number of eggs reached 10.5 eggs/ female. The total number of eggs/ female was 235.72 \pm 0.24 . In agreement with the obtained results, Qureshi et al. (1974), in Pakistan reported that the pre-ovipositional period of B. zonata was 14.2 days at $27 \pm 2$ ${ }^{\circ} \mathrm{C}$, , and the female deposited 279 eggs at $25^{\circ} \mathrm{C}$. In (1995), Hussain recorded 13 days prior to female oviposition after emergence. FAO/ IAEA action plan (2000), stated that the pre-ovipositional period, included sexual maturation was 8-16 days and therefore 10 to 23 days were needed to the first egg when the time for sexual maturity was included. The female laid an average of 137 eggs in batches.

The results are also nearly in accordance with those recorded by El-Gendy (2003) who found that the pre-ovipositional period was 14.6 and 26.6 days for 
females reared on peach and artificial diets, respectively. Female's fecundity varied from 372 to 734 eggs, when reared on banana and mandarin, respectively. The same trend was recorded by Amin (2003), El-Naggar (2004), Afia (2007), Shehata et al. (2008), and Farag (2009). On the other hand, El-Minshawy et. al., (1999) recorded a pre-ovipositional period of $45-60$ days at $25^{\circ} \mathrm{C}$.

Most of the female flies ceased egg deposition for 4-6 days before death. This result is in agreement with that recorded by El-Gendy (2003), Afia (2007) and Farag (2009) who reported 8.0 days at $24 \pm 3^{\circ} \mathrm{C}, 5.8$ and 6.2 days at $25 \pm 1^{\circ} \mathrm{C}$, respectively. Amin (2008) recorded 16.4 and 17.2 days at $25^{\circ} \mathrm{C}$, when females were fed on solid and liquid protein hydrolysate, respectively.

\subsection{Survival rate}

Data revealed that the average percentage of adult emergence was $58 \%$ at $25 \pm 1 \mathrm{C}^{\circ}$ and $54-60 \%$ R.H.

Table 2. Some biological characteristics of Bactrocera zonata under the laboratory conditions of $25 \pm 1 \mathrm{C}^{\circ}$ and $54 \%-60$ R.H.

\begin{tabular}{|c|c|c|}
\hline Duration (days) & Means \pm SE & Range \\
\hline Egg & $2.7 \pm 0.15$ & $1-3$ \\
\hline Larva & $5.8 \pm 0.28$ & $5-7$ \\
\hline Pupa & $10.2 \pm 0.13$ & $9-11$ \\
\hline Total developmental period & $18.7 \pm 0.25$ & $15-21$ \\
\hline Survival rate $\%$ & $58 \% \pm 0.44$ & $40-80 \%$ \\
\hline \multicolumn{3}{|l|}{ Longevity (days) d } \\
\hline Female & $50.6 \pm 1.44$ & 49- 54 \\
\hline Male & $47.3 \pm 1.4$ & $44-49$ \\
\hline \multicolumn{3}{|l|}{ Un-fed } \\
\hline Female & $2.8 \pm 0.38$ & $2-6$ \\
\hline Male & $3.3 \pm 0.46$ & $2-6$ \\
\hline \multicolumn{3}{|l|}{ Fecundity } \\
\hline Pre ovipositional period (days) & $16.6 \pm 1.97$ & $13-21$ \\
\hline Ovipositional period & $29.33 \pm 1.15$ & $28-32$ \\
\hline Post-ovipositional period & $4.6 \pm 0.28$ & $4-6$ \\
\hline Daily mean no. (Eggs/ female) & $10.5 \pm 1.13$ & $5-16$ \\
\hline Total no. eggs/ female & $235.72 \pm 6.2$ & $227-248$ \\
\hline Sex ratio \% (female : male ) & $1.2: 1.0$ & 1.3: $1.0-2: 1$ \\
\hline
\end{tabular}




\subsection{Sex ratio}

Sex ratio of $B$. zonata (female: males) was 1.2: 1 under the laboratory conditions of $25 \pm 1 \mathrm{C}^{\circ}$ and $54-60 \%$ R.H.

\subsection{Longevity}

When B. zonata adults were provided by water and a mixture of sugar and protein hydrolysate, they lived longer compared to those of unfed individuals. The female and male longevities were 50.6 and 47.3 days for the fed individuals and 2.8 and 3.3 for unfed ones, respectively at $25 \pm 1{ }^{\circ} \mathrm{C}$. This result is nearly similar to that recorded by El-Gendy (2003), Afia (2007) and Farag (2009) who reported these periods for male and female as $59.6 \& 82.5,64.2 \& 76.8$ and $62.1 \& 76.2$ days at $25 \pm 1^{\circ} \mathrm{C}$, respectively. However the obtained results differed than those reported by El- Minshawy et al. (1999) who recorded 100.0 and 145.0 days for male and female at $25^{\circ} \mathrm{C}$, respectively .

\section{ACKNOWLEDGEMENTS}

The authors wish to thank Dr. Yussef A. Mahmoud, Department of Pests and Plant Protection, National Research Center, Dokki, Giza for his helpful advice for rearing $B$. zonata and providing the diet ingredients.

\section{REFERENCES}

1. Afia, Y. E. 2007. Comparative studies on the biology and ecology of the two fruit flies, in Egypt Bactrocera zonata (Saunders) and Ceratitis capitata (Wiedmann). Ph. D. Thesis, Cairo Univ., Egypt, 301 pp.

2. Amin, A. A. 2003. Studies on peach fruit fly, Bactrocera zonata (Saund.) and its control in Fayoum Governorate. M. Sc. Thesis, Fac. Agric., Fayoum Univ., Egypt, $128 \mathrm{pp}$.

3. Amin, A. A. 2008. Ecological and biological studies on the peach and Mediterranean fruit flies in Fayoum Governorate. Ph.D. Thesis, Fac Agric., Fayoum Univ., Egypt, 251 pp.

4. Awadallah, A. 1978. First report of project for control of Mediterranean fruit fly using sterile insect technique at Fayoum Governorate during the period from June 1974 to June 1978. (PPRI, ARC, library). Cited by Amin (2008).

5. Boller, E. F. 1985. Rhagoletis cerasi and Ceratitis capitata. In: Sing, P., Moore, RF., editors. Handbook of Insect Rearing. Elsevier, Amsterdam, the Netherlands, 2: $135-144$. 
6. Christenson, L. D. and R. H. Foote. 1960. Biology of fruit flies. Ann. Rev. Ent., 5: $171-192$.

7. Duyck, P. F., J. F. Strelin and S. Quilici. (2004): Survival and development of different life stages of Bactrocera zonata (Diptera: Tephritidae) reared at five constant temperatures compared to other fruit fly species. Bull. Ent. Res., 94:8993.

8. El-Gendy, I. R. I. 2003. Studies on peach fruit fly, Bactrocera zonata (Saund.) at El-Beheira Governorate. M. Sc. Thesis, Fac. Agric., Alex. Univ., Egypt, 133 pp.

9. El-Naggar, H. M. 2004. Studies on some Apple Insect Pests. M. Sc. Thesis, Fac. Agric., Zagazig Univ., Egypt, 124 pp.

10. El-Minshawy, A. M., M. A. Al-Eryan and A. I. Awad. 1999. Biological and morphological studies on the guava fruit fly Bactrocera zonata (Diptera: Tephritidae) found recently in Egypt. Proceeding of 8th Nat. Conf. of pest and diseases of vegetables and fruits in Ismailia, Egypt, p.71 -81.

11. Elson-Harris, M. M. 1988. Morphology of the immature stages of Dacus tryon (Froggatt) (Diptera: Tephritidae). J. Aust. ent. Soc., 27: 91-98

12. FAO/IAEA (2000): Action Plan: Peach Fruit Fly Bactrocera zonata (Saunders). Joint FAO/IAEA Division, Vienna (AT).

13. Farag, Marwa M. 2009. Heat requirements as a tool for predicting the annual generation of peach fruit fly, Bactrocera zonata (Saunders) (Diptera: Tephritidae). M. Sc. Thesis, Fac. Agric., Cairo Univ., Egypt, 111 pp.

14. Fletcher, B. S. 1987. The biology of Dacine fruit flies. Ann. Rev. Entomol., 32: 115-114.

15. Hussain, T. 1995. Demography and population genetics of Dacus zonatus (Saunders). Ph. D. thesis, Fac. Sci., Punjab Lahore Univ., Pakistan, pp212..

16. Masood, K. K., F S. Mohammad and J. Ghulam. 2006. Effect of different extracts of harmal (Peganum harmala I.), rhizomes of kuth (Saussurea lappa c. b. clarke) and balchar (Valariana officianalis I.) on the settling and growth of peach fruit fly, (Bactrocera zonata Saunders). Pak. Entomol., vol. 28, no.1, 2006.

17. Mohamed, A. M. 2000. Effect of constant temperatures on the development of the peach fruit fly, Bactrocera zonata (Saunders) (Diptera: Tephritidae). Assiut J. Agric. Sci., 31: 329- 337.

18. Mohamed, A. M. 2002. Seasonal abundance of the peach fruit fly, Bactrocera zonata (Saunders) (Diptera: Tephritidae) with relation to prevailing weather factors in Upper Egypt. Assiut J. Agric. Sci., 33(2): 195-207.

19. OEPP/EPPO. 2005. Data sheets of Bactrocera zonata. Bulletin OEPP/ EPPO Bulletin. 35: 371-373. 
20. Qureshi, Z. A., M. Ashraf, A. R. Bughio and S. Hussain. 1974. Rearing, reproductive behavior and gamma sterilization on fruit fly, Dacus zonatus (Saunders) (Diptera: Tephritidae). Entomol. Exp. Appl., 17: 504 - 510.

21. Qureshi, Z. A., T. Hussain, J. R. Carey and R. V. Dowell. 1993. Effects of temperature on development of Bactrocera zonata (Saunders) (Diptera: Tephritidae). Pan-Pacific entomologist, 69(1): 71-76.

22. Shehata, N.F., M. W.F. Younes and Y.A. Mahmoud. 2008. Biological studies on the Peach Fruit Fly, Bactrocera zonata (Saunders) in Egypt. J. Appl. Sci. Res., 4(9): 1103-1106. 


\title{
مورفولوجيا وبعض الخواص البيولوجية لذبابة ثمار الذوخ
}

\section{BACTROCERA ZONATA (SAUND.) (DIPTERA: TEPHRITIDAE)}

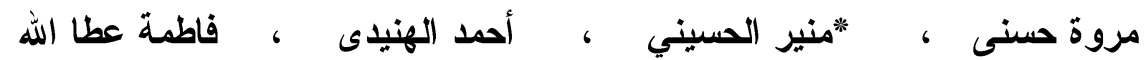

$$
\text { * قسم بحوث الدكافحة الحيوية - معهز بحوث وقابة النباتات - مركز البحوث الزراعية - الجيزة - مصر }
$$

تعتبر ذبابة ثمار الخوخ Bactrocera zonata (Saund.) (Diptera: Tephritidae) و احدة من حشرات عائلة تقريتيدى الخطيرة التي تهاجم الفاكهة الاستو ائية وشبه الاستو ائية. تظهر الآفة في

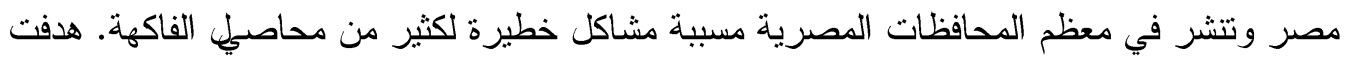
الدر اسة الحالية إلى التركيز على بعض الصفات المورفولوجية و البيولوجية للأطوار المختلفة للآفة تحت الظروف المعملية. تم وصف وقياس وتصوير مختلف أطوار الآفة. شملت الدراسات البيولوجية مدة أعمار الأطوار غبر الكاملة المختلفة، الخصوبة، طول حياة الحشرة الكاملة، معدل البقاء، و النسبة ولهابة

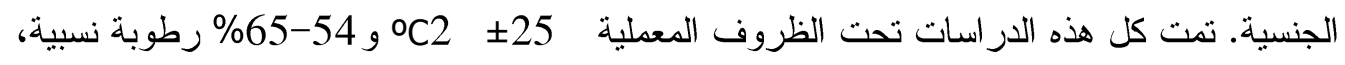
و10:1414

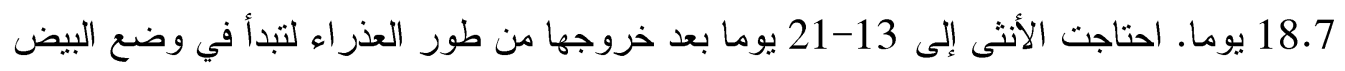

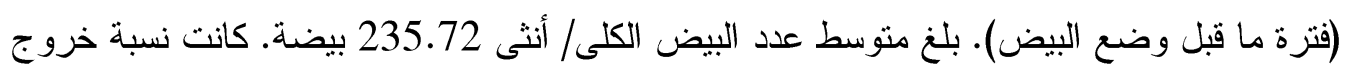

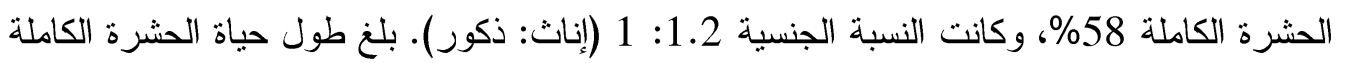
من الإناث و الذكور 50.6 و47.3 يوما في حالة الأفراد التي تم تغذيتها بينما بلغت 2.8 و 3.1 يومان الكان

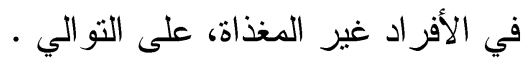

